University of Texas Rio Grande Valley

ScholarWorks @ UTRGV

Mechanical Engineering Faculty Publications

and Presentations

2012

\title{
Electrospun carbon nanofibers decorated with various amounts of electrochemically-inert nickel nanoparticles for use as high- performance energy storage materials
}

\author{
Liwen Ji \\ North Carolina State University at Raleigh \\ Zhan Lin \\ North Carolina State University at Raleigh \\ Mataz Alcoutlabi \\ The University of Texas Rio Grande Valley, mataz.alcoutlabi@utrgv.edu \\ Ozan Toprakci \\ North Carolina State University at Raleigh \\ Yingfang Yao \\ North Carolina State University at Raleigh \\ See nextpage for addditional arthors: \\ Part of the Mechanical Engineering Commons
}

\section{Recommended Citation \\ Ji, L., Lin, Z., Alcoutlabi, M., Toprakci, O., Yao, Y., Xu, G., Li, S., \& Zhang, X. (2012). Electrospun carbon nanofibers decorated with various amounts of electrochemically-inert nickel nanoparticles for use as high-performance energy storage materials. RSC Adv., 2(1), 192-198. https://doi.org/10.1039/ C1RA00676B}

This Article is brought to you for free and open access by the College of Engineering and Computer Science at ScholarWorks @ UTRGV. It has been accepted for inclusion in Mechanical Engineering Faculty Publications and Presentations by an authorized administrator of ScholarWorks @ UTRGV. For more information, please contact justin.white@utrgv.edu,william.flores01@utrgv.edu. 


\section{Authors}

Liwen Ji, Zhan Lin, Mataz Alcoutlabi, Ozan Toprakci, Yingfang Yao, Guanjie Xu, Shuli Li, and Xiangwu Zhang

This article is available at ScholarWorks @ UTRGV: https://scholarworks.utrgv.edu/me_fac/9 


\title{
RSC Advances
}

\section{Electrospun carbon nanofibers decorated with various amounts of electrochemically-inert nickel nanoparticles for use as high-performance energy storage materials $\uparrow$}

\author{
Liwen Ji, $₫$ Zhan Lin, $\$$ Mataz Alcoutlabi, $\$$ Ozan Toprakci, $\$$ Yingfang Yao, Guanjie Xu, Shuli Li and Xiangwu Zhang*
}

Received 5th September 2011, Accepted 8th September 2011

DOI: 10.1039/c1ra00676b

Carbon nanofibers decorated with various amounts of electrochemically-inert metallic nickel nanoparticles are synthesized through electrospinning and carbonization processes. The morphology and composition of Ni nanoparticles in carbon nanofibers are controlled by preparing different nanofiber precursors. The lithium-ion battery performance evaluations indicated that the content of electrochemically-inert Ni nanoparticles in carbon nanofibers has a great influence on the final electrochemical performance. For example, at certain Ni contents, these composite nanofibers display excellent electrochemical performance, such as high reversible capacities, good capacity retention, and excellent rate performance, when directly used as binder-free anodes for rechargeable lithium-ion batteries. However, when the $\mathrm{Ni}$ content is too low or too high, the corresponding electrodes show low reversible capacities although they still have good reversibility and rate performance.

\section{Introduction}

Rechargeable lithium-ion batteries (LIBs) have been widely used for energy storage in electronic devices such as laptops, cell phones, and digital cameras, and they are currently being studied for advanced electric and hybrid vehicles. ${ }^{1-7}$ It is very important to develop LIBs with high capacity and good rate capability to meet the energy demands of our society. ${ }^{1-7}$ Since the performance of a battery depends decisively on the properties of the electrode materials, it is necessary to seek and design novel nanostructured electrodes with large reversible storage capacity, high charge/discharge efficiency, and good rate capability. Nanostructured electrodes exhibit high surface areas and good transport properties, and they can offer an exciting solution to achieve increased storage capacity and enhanced energy/powder densities through fast interfacial kinetics. ${ }^{1-7}$ However, singlephase nanoscale electrodes are certainly not a panacea and they may not resolve all of the limitations faced by their bulk counterparts when used as electrodes for rechargeable LIBs because of their intrinsic material properties in both thermodynamics and kinetics aspects. ${ }^{2,-10}$ In addition, single-phase nanostructure electrodes often have undesirable side reactions with the electrolyte that can lead to low reversibility and poor capacity retention. ${ }^{2,4-10}$ Therefore, the integration of different components into heterogeneous nanostructures is of particular

Fiber and Polymer Science Program, Department of Textile Engineering, Chemistry and Science, North Carolina State University, Raleigh, NC 27695-8301,USA. E-mail: xiangwu_zhang@ncsu.edu; Fax: 919-515-6532; Tel: $919-515-6547$

$\uparrow$ Electronic Supplementary Information (ESI) available. See DOI: $10.1039 / \mathrm{c} 1 \mathrm{ra} 00676 \mathrm{~b}$

+ These authors contributed equally to this work. importance because, in these well-designed multi-phase nanostructures, each component can address different problems and their combinative effects can eventually help realize the full potential of the different components in terms of energy/power density, cycle life, rate performance, etc.

Nanostructured carbon-based electrodes, such as nanotubes, nanofibers and graphene, exhibit good chemical and thermal stability, excellent mechanical stress tolerance (ductility), extraordinary electronic and ionic conductivities, and also considerable Li-storage ability. ${ }^{2,11-21}$ Often, a carbon matrix is used as the host to accommodate Li-active nanoparticles, such as $\mathrm{Si}, \mathrm{Ge}$, $\mathrm{Sn}$ and some transition metal oxides, and to buffer the large volume change resulting from repeated lithium insertion and extraction. ${ }^{1,2,4,12,14,22}$ The resultant carbon-based multiphase nanocomposite electrodes show improved electrochemical performance compared to individual carbon and Li-active nanoparticles. Among all nanostructured carbon materials, carbon nanofibers $(\mathrm{CNFs})$ are a promising one-dimensional structure with high aspect ratio and high surface-to-volume ratio, which can offer a direct pathway for efficient charge transport along the fiber axis when used as anodes for rechargeable LIBs. CNFs can also form interconnected network structures that can facilitate the percolation of electric charges throughout the electrodes and provide large surface areas that facilitate the fast diffusion of $\mathrm{Li}$ ions. ${ }^{2,23}$

Electrochemically-inert transition metal nanoparticles, such as $\mathrm{Ni}, \mathrm{Cu}, \mathrm{Fe}$, and $\mathrm{Nb}$, are inactive with $\mathrm{Li}^{3,22}$ However, these transition metal nanoparticles can create conducting networks in electrodes to promote the electrical contact of the electrodes and to provide better endurance of high current densities upon charge/discharge cycling. These nanoscale transition metal 
nanoparticles also show the potential to stabilize the solid electrolyte interface (SEI) film during the cycle process, reduce the initial irreversible capacity, and improve the Coulombic efficiency and cycling performance of electrodes at high current densities. ${ }^{3,22,24-28}$ Hence, incorporating these transition metal particles into nanoscale carbon for use as LIB electrodes has a great beneficial impact on the overall battery performance.

In this work, CNFs decorated with different amounts of electrochemically-inert $\mathrm{Ni}$ nanoparticles are prepared via the electrospinning of polyacrylonitrile (PAN) solutions containing various concentrations of nickel(II) acetate tetrahydrate $\left(\mathrm{Ni}(\mathrm{OAc})_{2} \cdot 4 \mathrm{H}_{2} \mathrm{O}\right)$ and sequential thermal treatments in both air and inert gas environments at high temperatures. These Ni/C composite nanofibers, in the form of freely-standing films, are directly used as binder-free anodes (negative electrodes) for LIBs. Results indicate that the Ni content in the CNF matrix has a large influence on the final electrochemical performance. At certain $\mathrm{Ni}$ contents, $\mathrm{Ni} / \mathrm{C}$ composite nanofibers exhibit high reversible capacity, enhanced cyclability, and excellent rate capability, which have been problematic for the pure CNF electrodes. These results demonstrated that decorating CNFs with electrochemically-inert transition metal nanoparticles could provide a relatively simple, scalable, and economical route to prepare nanomaterials for use in LIB electrodes. In addition, this novel strategy may also open a new avenue to design onedimensional transitional metal nanoparticle-loaded carbon nanofibers for lithium-air batteries, fuel cells, and other energy storage and conversation systems.

\section{Experimental}

\section{Materials preparation and characterization}

PAN $(\mathrm{Mw}=150$ 000) was purchased from Fisher Scientific, and $\mathrm{Ni}(\mathrm{OAc})_{2} \cdot 4 \mathrm{H}_{2} \mathrm{O}$ salt $(99.99 \%)$ and solvent $N, N$-dimethylformamide (DMF) were purchased from Aldrich. All these reagents were used without further purification. DMF solutions of PAN $(8 \mathrm{wt} \%)$ containing different amounts of $\mathrm{Ni}(\mathrm{OAc})_{2} \cdot 4 \mathrm{H}_{2} \mathrm{O}(15,30$, and $50 \mathrm{wt} \%$ ) were prepared at $60{ }^{\circ} \mathrm{C}$. Mechanical stirring was applied for at least $72 \mathrm{~h}$ in order to obtain homogeneouslydistributed solutions.

A variable high-voltage power supply (Gamma ES40P) was used to provide a high voltage of about $15 \mathrm{kV}$ for electrospinning with $0.5 \mathrm{ml} \mathrm{h}^{-1}$ flow rate and $15 \mathrm{~cm}$ needle-to-collector distance. The electrospun $\mathrm{Ni}(\mathrm{OAc})_{2} \cdot 4 \mathrm{H}_{2} \mathrm{O} / \mathrm{PAN}$ precursor nanofibers were first stabilized in an air environment at $280{ }^{\circ} \mathrm{C}$ for $6 \mathrm{~h}$ (heating rate was $5{ }^{\circ} \mathrm{C} \mathrm{min}{ }^{-1}$ ) and then carbonized at $600{ }^{\circ} \mathrm{C}$ for $8 \mathrm{~h}$ in an argon atmosphere (heating rate was $2{ }^{\circ} \mathrm{C} \min ^{-1}$ ) to form $\mathrm{Ni} / \mathrm{C}$ composite nanofibers. Elemental analysis indicated that the $\mathrm{Ni}$ contents of $\mathrm{Ni} / \mathrm{C}$ nanofibers prepared from $\mathrm{Ni}(\mathrm{OAc})_{2} \cdot 4 \mathrm{H}_{2} \mathrm{O} / \mathrm{PAN}$ precursors with $15,30,50 \mathrm{wt} \% \mathrm{Ni}$ salt were about 5,12 , and $16 \mathrm{wt}^{\%}$, respectively.

The morphology and microstructures of $\mathrm{Ni}(\mathrm{OAc})_{2} \cdot 4 \mathrm{H}_{2} \mathrm{O} / \mathrm{PAN}$ precursor nanofibers and the carbonized nanofibers were evaluated using scanning electron microscopy (JEOL 6400F Field Emission SEM at $5 \mathrm{kV}$ ) and transmission electron microscopy (Hitachi HF-2000 TEM at $200 \mathrm{kV}$ ) coupled with energy-dispersive X-ray spectroscopy (EDX). Thermal properties of the electrospun nanofibers were evaluated using differential scanning calorimetry (DSC) from 25 to $400{ }^{\circ} \mathrm{C}$ at a heating rate of $10{ }^{\circ} \mathrm{C} \mathrm{min}{ }^{-1}$ in a nitrogen environment (Perkin Elmer Diamond Series DSC with Intracooler). Thermo-gravimetric analysis (TGA) was also used to determine the weight loss of nanofibers at $10{ }^{\circ} \mathrm{C} \mathrm{min}^{-1}$ from 25 to $800{ }^{\circ} \mathrm{C}$ in air environment (TA Instruments Hi-Res TGA 2950). The structural variations of carbonized nanofibers were identified by wide angle X-ray diffraction (WAXD, Philips X'Pert PRO MRD HR X-Ray Diffraction System, $\mathrm{Cu}-\mathrm{K} \alpha, \lambda=1.5405$ Å.). $\mathrm{X}$-Ray photoelectron spectroscopy (XPS) was also used to measure elemental compositions and chemical states.

\section{Electrochemical evaluation}

Electrochemical performance was evaluated using 2032 button coin cells (Hohsen Corp.). Ni/C nanofibers were directly attached onto copper foils to be used as the binder-free working electrode. Lithium foil ( $0.38 \mathrm{~mm}$ thick, Aldrich) and Separion S240 P25 (Degussa AG, $25 \mu \mathrm{m}$ ) were used as the counter electrode and separator, respectively. The electrolyte used was $1 \mathrm{M}$ lithium hexafluorophosphate $\left(\mathrm{LiPF}_{6}\right)$, dissolved in $1 / 1(\mathrm{v} / \mathrm{v})$ ethylene carbonate (EC)/ethyl methyl carbonate (EMC) (Ferro Corp.). Coin cells were assembled in a high-purity argon-filled glove box. Cyclic voltammetry (CV) measurements were performed on an AQ4 Gamry Reference 600 electrochemical workstation with a voltage ranging from 0.001 to $3.0 \mathrm{~V}$ at a scan rate of $0.05 \mathrm{mV} \mathrm{s}^{-1}$. Charge (lithium insertion) and discharge (lithium extraction) were conducted using an Arbin automatic battery cycler at different current densities between cut-off potentials of 0.01 and $2.80 \mathrm{~V}$.

\section{Results and discussion}

\section{Structure characterization}

Fig. 1 and S1 (see ESI $\dagger$ ) show SEM and TEM images of electrospun $\mathrm{Ni}(\mathrm{OAc})_{2} \cdot 4 \mathrm{H}_{2} \mathrm{O} / \mathrm{PAN}$ precursor nanofibers with different $\mathrm{Ni}(\mathrm{OAc})_{2} \cdot 4 \mathrm{H}_{2} \mathrm{O}$ concentrations, respectively. Electrospun $\mathrm{Ni}(\mathrm{OAc})_{2} \cdot 4 \mathrm{H}_{2} \mathrm{O} / \mathrm{PAN}$ nanofibers are straight and exhibit homogeneously-distributed diameters in the range of 500 to $800 \mathrm{~nm}$. However, the surface morphology of these electrospun nanofibers is irregular and uneven. In addition, with increase in $\mathrm{Ni}(\mathrm{OAc})_{2} \cdot 4 \mathrm{H}_{2} \mathrm{O}$ concentration, the surface becomes rougher and some undulating structures and even pores are clearly shown. Moreover, with the increase of $\mathrm{Ni}(\mathrm{OAc})_{2} \cdot 4 \mathrm{H}_{2} \mathrm{O}$ concentration, the diameter of the $\mathrm{Ni}(\mathrm{OAc})_{2} \cdot 4 \mathrm{H}_{2} \mathrm{O} / \mathrm{PAN}$ nanofibers also increases, and $\mathrm{Ni}(\mathrm{OAc})_{2} \cdot 4 \mathrm{H}_{2} \mathrm{O} / \mathrm{PAN}$ nanofibers with different $\mathrm{Ni}(\mathrm{OAc})_{2} \cdot 4 \mathrm{H}_{2} \mathrm{O}$ concentrations of 15,30 , and $50 \mathrm{wt} \%$ have average diameters of about 500, 700, and $900 \mathrm{~nm}$, respectively. With increase in $\mathrm{Ni}(\mathrm{OAc})_{2} \cdot 4 \mathrm{H}_{2} \mathrm{O}$ concentration, the solution viscosity increases and results in larger diameters for $\mathrm{Ni}(\mathrm{OAc})_{2}$. $4 \mathrm{H}_{2} \mathrm{O} / \mathrm{PAN}$ nanofibers. ${ }^{29-32}$

The DSC analysis of pure PAN and $\mathrm{Ni}(\mathrm{OAc})_{2} \cdot 4 \mathrm{H}_{2} \mathrm{O} / \mathrm{PAN}$ nanofiber precursors was conducted at a heating rate of $10{ }^{\circ} \mathrm{C}$ $\min ^{-1}$ in nitrogen environment, as shown in Fig. 2A. Pure PAN nanofibers exhibit a relatively large and sharp exothermic peak at around $290{ }^{\circ} \mathrm{C}$ and this might be due to multiple complex chemical reactions, such as dehydrogenation, instantaneous cyclization, and crosslinking reactions associated with the oxidative stabilization of PAN.,11,23,29-31 In the presence of $\mathrm{Ni}(\mathrm{OAc})_{2} \cdot 4 \mathrm{H}_{2} \mathrm{O}$ salt, the exothermic peak shifts to lower temperatures. At the same time, the peak intensity, which 


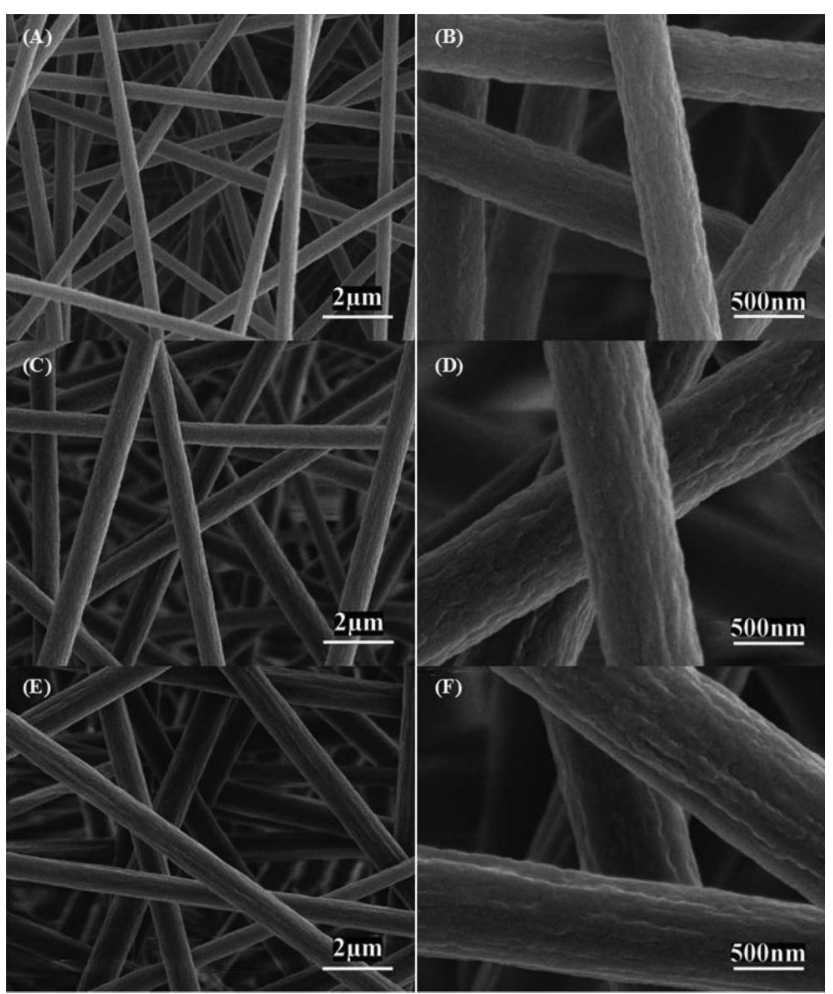

Fig. 1 SEM images of $\mathrm{Ni}(\mathrm{OAc})_{2} \cdot 4 \mathrm{H}_{2} \mathrm{O} / \mathrm{PAN}$ composite nanofibers with different $\mathrm{Ni}(\mathrm{OAc})_{2} \cdot 4 \mathrm{H}_{2} \mathrm{O}$ concentrations: (A, B) 15 , (C, D) 30, and (E, F) $50 \mathrm{wt} \%$.

indicates the total heat of reaction, decreases as $\mathrm{Ni}(\mathrm{OAc})_{2} \cdot 4 \mathrm{H}_{2} \mathrm{O}$ concentration increases. The reductions in reaction temperature and peak intensity probably resulted from the interactions between PAN and $\mathrm{Ni}(\mathrm{OAc})_{2} \cdot 4 \mathrm{H}_{2} \mathrm{O}$ that decrease the formation of free radicals on the nitrile groups in PAN and subsequently lower their recombination and the heat of reaction. ${ }^{23,29-31,33}$ In addition, $50 \mathrm{wt} \% \mathrm{Ni}(\mathrm{OAc})_{2} \cdot 4 \mathrm{H}_{2} \mathrm{O} / \mathrm{PAN}$ nanofibers display an indistinguishable exothermic peak along with a relatively wide endothermic peak. Generally, any endotherm or exotherm is an indication of structural change. PAN degrades well below the melting temperature because it undergoes certain exothermic reactions leading to the formation of ladder structures. ${ }^{23,29-32,34}$ The downshifted exothermic peak in the presence of $50 \mathrm{wt} \% \mathrm{Ni}(\mathrm{OAc})_{2} \cdot 4 \mathrm{H}_{2} \mathrm{O}$ provides the evidence that the $\mathrm{Ni}(\mathrm{OAc})_{2} \cdot 4 \mathrm{H}_{2} \mathrm{O}$ compound accelerates the onset of oxidative stabilization. ${ }^{23,29-31,33}$ Furthermore, the endothermic peak only appears when the $\mathrm{Ni}(\mathrm{OAc})_{2} \cdot 4 \mathrm{H}_{2} \mathrm{O}$ concentration increases to $50 \mathrm{wt} \%$. The decomposition of $\mathrm{Ni}(\mathrm{OAc})_{2} \cdot 4 \mathrm{H}_{2} \mathrm{O}$ was studied by Mohamed et al. ${ }^{35}$ and their DSC results showed several endothermic events. For example, there are two overlapping endothermic peaks located at 249 and $360{ }^{\circ} \mathrm{C}$, indicating the decomposition of $\mathrm{Ni}(\mathrm{OAc})_{2} \cdot 4 \mathrm{H}_{2} \mathrm{O}$. There is also another endothermic event above $400{ }^{\circ} \mathrm{C}$, which can be attributed to the decomposition of $\mathrm{NiO}$ to $\mathrm{Ni}$ metal. ${ }^{35}$ Other literature results also show that the non-isothermal decomposition of $\mathrm{Ni}(\mathrm{OAc})_{2} \cdot 4 \mathrm{H}_{2} \mathrm{O}$ is a complex multi-step reaction. ${ }^{36-38}$ These results agree with our DSC data for the $50 \mathrm{wt} \% \mathrm{Ni}(\mathrm{OAc})_{2} \cdot 4 \mathrm{H}_{2} \mathrm{O} /$ PAN nanofiber precursor, where the existence of the endothermic peak at around $300{ }^{\circ} \mathrm{C}$ could be the result of several complex thermal effects of $\mathrm{Ni}(\mathrm{OAc})_{2} \cdot 4 \mathrm{H}_{2} \mathrm{O} .^{36-38}$

The thermal studies of pure PAN and $\mathrm{Ni}(\mathrm{OAc})_{2} \cdot 4 \mathrm{H}_{2} \mathrm{O} / \mathrm{PAN}$ precursor nanofibers with $\mathrm{Ni}(\mathrm{OAc})_{2} \cdot 4 \mathrm{H}_{2} \mathrm{O}$ concentrations of 15 , 30 , and $50 \mathrm{wt} \%$ were also carried out using TGA in air atmosphere, as shown in Fig. 2B. Pure PAN nanofibers degrade at about $320{ }^{\circ} \mathrm{C}$, however, $\mathrm{Ni}(\mathrm{OAc})_{2} \cdot 4 \mathrm{H}_{2} \mathrm{O} / \mathrm{PAN}$ nanofibers begin losing weight at a lower temperature of about $250{ }^{\circ} \mathrm{C}$ due to the decomposition of $\mathrm{Ni}(\mathrm{OAc})_{2} \cdot 4 \mathrm{H}_{2} \mathrm{O}$ salt. The decomposition of $\mathrm{Ni}(\mathrm{OAc})_{2} \cdot 4 \mathrm{H}_{2} \mathrm{O}$ salt also destroys their interactions with PAN chains and accelerates the oxidative reactions of PAN nanofibers, which result in the lower decomposition temperature of PAN in $\mathrm{Ni}(\mathrm{OAc})_{2} \cdot 4 \mathrm{H}_{2} \mathrm{O} / \mathrm{PAN}$ nanofibers. ${ }^{23,29-32,34}$ Moreover, the final weight loss of pure PAN nanofibers is almost $100 \%$ due to its complete decomposition in air. However, the final weight percentages of $\mathrm{Ni}(\mathrm{OAc})_{2} \cdot 4 \mathrm{H}_{2} \mathrm{O} / \mathrm{PAN}$ composite nanofibers do not reach zero due to the fact that the TGA characterizations were carried out in air environment and this leads to the formation of Ni-containing compounds such as $\mathrm{NiO}$ after the decomposition (or oxidation) of $\mathrm{Ni}(\mathrm{OAc})_{2} \cdot 4 \mathrm{H}_{2} \mathrm{O}$ salt.

$\mathrm{Ni}(\mathrm{OAc})_{2} \cdot 4 \mathrm{H}_{2} \mathrm{O} / \mathrm{PAN}$ precursor nanofibers with different $\mathrm{Ni}(\mathrm{OAc})_{2} \cdot 4 \mathrm{H}_{2} \mathrm{O}$ concentrations were stabilized at $280{ }^{\circ} \mathrm{C}$ in air environment, following by carbonization at $600{ }^{\circ} \mathrm{C}$ in argon gas. The crystallinity and phase composition of heat-treated nanofibers were investigated by WAXD (Fig. 3). WAXD patterns show that the composite nanofibers exhibit diffraction peaks at $2 \theta$ of $44.4^{\circ}, 51.9^{\circ}$, and $76.5^{\circ}$, which can be ascribed to the
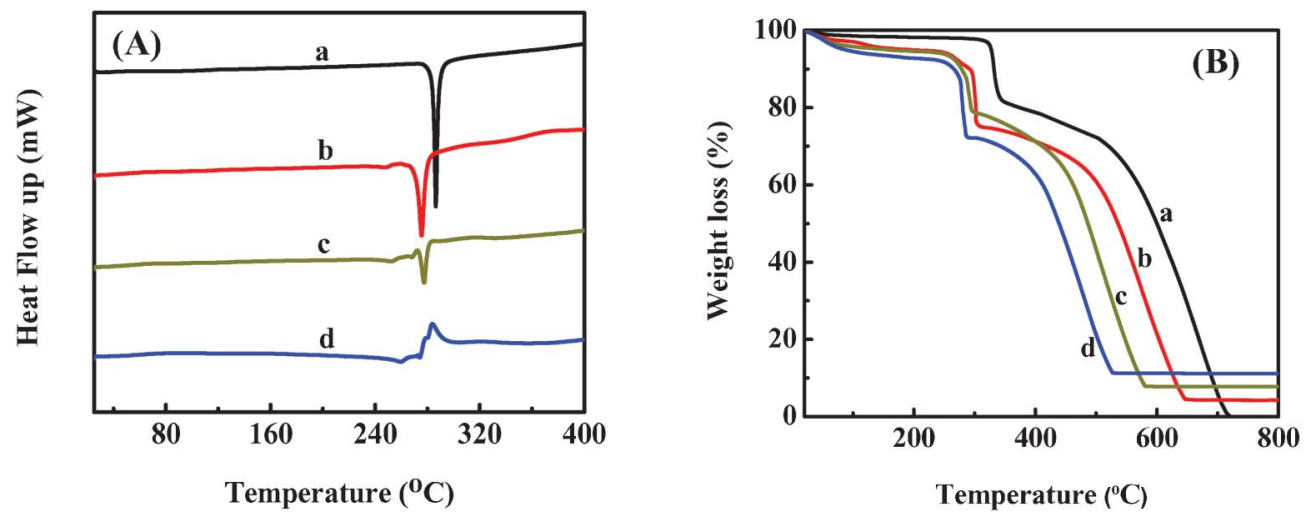

Fig. 2 DSC (A) and TGA (B) thermograms of $\mathrm{Ni}(\mathrm{OAc})_{2} \cdot 4 \mathrm{H}_{2} \mathrm{O} / \mathrm{PAN}$ composite nanofibers with different $\mathrm{Ni}(\mathrm{OAc})_{2} \cdot 4 \mathrm{H}_{2} \mathrm{O}$ concentrations: (a) 0 (pure PAN), (b) 15 , (c) 30 , and (d) $50 \mathrm{wt} \%$. 


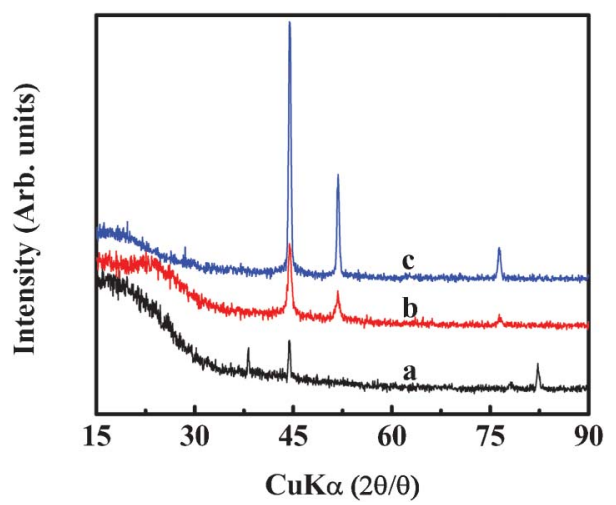

Fig. 3 WAXD patterns of $\mathrm{Ni} / \mathrm{C}$ composite nanofibers carbonized from $\mathrm{Ni}(\mathrm{OAc})_{2} \cdot 4 \mathrm{H}_{2} \mathrm{O} / \mathrm{PAN}$ precursors with different $\mathrm{Ni}(\mathrm{OAc})_{2} \cdot 4 \mathrm{H}_{2} \mathrm{O}$ concentrations: (a) 15 , (b) 30 , and (c) $50 \mathrm{wt} \%$.

(111), (200), and (220) planes of $\mathrm{Ni}$ crystal, respectively. $3,39,40$ With increase in $\mathrm{Ni}(\mathrm{OAc})_{2} \cdot 4 \mathrm{H}_{2} \mathrm{O}$ concentration, the diffraction peaks become stronger. All these peaks confirm the formation of $\mathrm{Ni} / \mathrm{C}$ composite nanofibers during the heat-treatment process. Further elemental analysis indicates that the $\mathrm{Ni}$ contents of $\mathrm{Ni} / \mathrm{C}$ composite nanofibers prepared from $\mathrm{Ni}(\mathrm{OAc})_{2} \cdot 4 \mathrm{H}_{2} \mathrm{O} / \mathrm{PAN}$ precursors with $15,30,50 \mathrm{wt}^{\circ} \mathrm{Ni}$ salt are about 5,12 , and $16 \mathrm{wt} \%$, respectively. The formation of metallic $\mathrm{Ni}$ may be caused by the reducing environment (e.g. some reducing products, such as hydrogen, activated carbon, charcoal, etc.) created during the carbonization process. ${ }^{3,41-44}$ In addition, a broad diffraction peak at around $25.0^{\circ}$ (002) also appears in Fig. 3, indicating the disordered structure of typical carbon materials in the as-prepared $\mathrm{Ni} / \mathrm{C}$ composite nanofibers. ${ }^{29,31,39}$

Fig. 4 shows SEM images of Ni/C composite nanofibers with different $\mathrm{Ni}$ contents of 5,12 , and $16 \mathrm{wt} \%$. It is seen that the morphology of Ni/C nanofibers is similar to that of the corresponding $\mathrm{Ni}(\mathrm{OAc})_{2} \cdot 4 \mathrm{H}_{2} \mathrm{O} / \mathrm{PAN}$ precursors shown in Fig. 1. However, spherical Ni particles with size around $20 \mathrm{~nm}$ are found for $\mathrm{Ni} / \mathrm{C}$ nanofibers with 12 and $16 \mathrm{wt} \% \mathrm{Ni}$. Ni particles are barely seen on $5 \mathrm{wt} \% \mathrm{Ni} / \mathrm{C}$ nanofibers (Fig. 4A,B), which might be due to the relatively small amount of $\mathrm{Ni}$ particles in these nanofibers. For Ni/C nanofibers with 12 and $16 \mathrm{wt}^{\%} \mathrm{Ni}$, the presence of $\mathrm{Ni}$ nanoparticles can be further observed from the TEM images shown in Fig. S2 and the corresponding EDX spectra in Fig. S3. $\dagger$ With increase in Ni content (from 5 to 12 and $16 \mathrm{wt}^{\%} \%$ ), more and more Ni particles

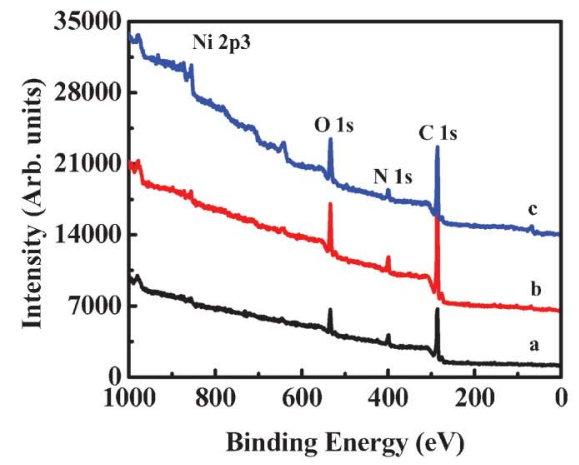

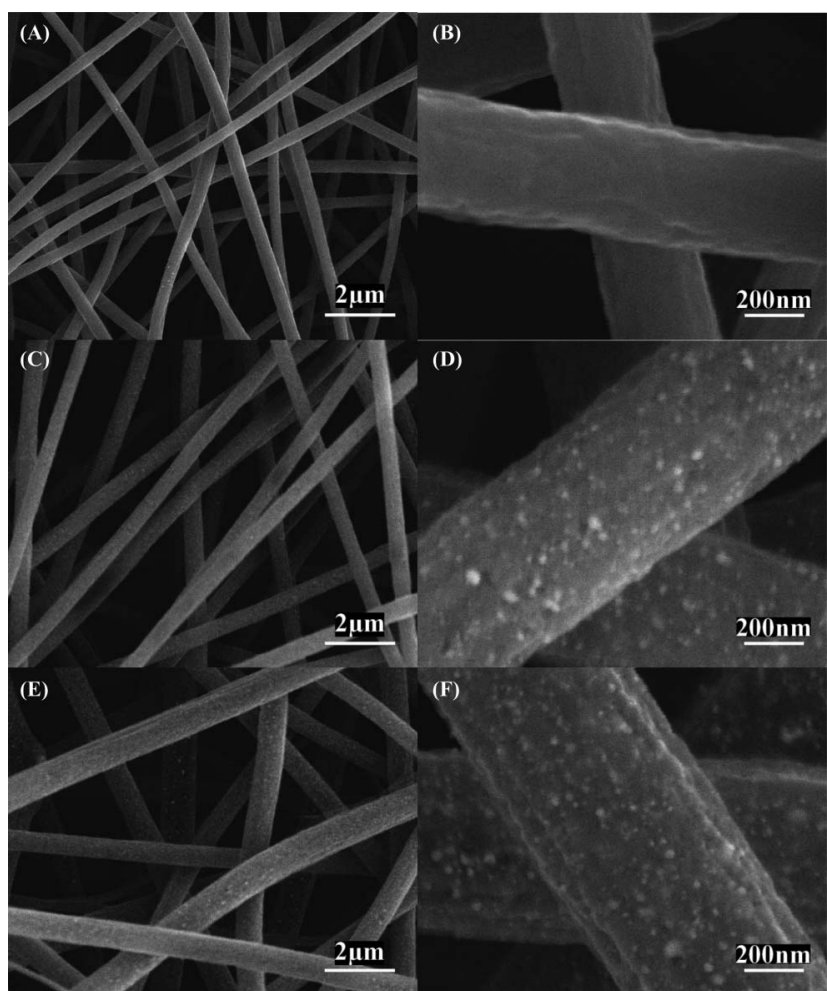

Fig. 4 SEM images of $\mathrm{Ni} / \mathrm{C}$ composite nanofibers with different $\mathrm{Ni}$ contents: (A, B) 5, (C, D) 12, and (E, F) $16 \mathrm{wt} \%$.

are found in both SEM and TEM images. In addition, as shown in the EDX spectra in Fig. S3, oxygen peaks are also seen for carbonized nanofibers, which may indicate the formation of amorphous $\mathrm{NiO}$ impurities during the thermal treatment process. However, the XRD curves in Fig. 3 do not show any $\mathrm{NiO}$ peak, and this may be caused by the small content of $\mathrm{NiO}$ impurity or their amorphous nature.

In order to determine the surface bond state of the $\mathrm{Ni}$ component in Ni/C nanofiber anodes, XPS analysis was conducted. Fig. 5 shows XPS spectra of Ni/C composite nanofibers. The peak at $853 \mathrm{eV}$ for $\mathrm{Ni} 2 \mathrm{p}_{3 / 2}$ indicates the existence of $\mathrm{Ni}^{0}{ }^{26,45}$ However, the $\mathrm{Ni} 2 \mathrm{p}_{3 / 2}(855 \mathrm{eV})$ peak shows that there may also exist $\mathrm{NiO}$ impurities $\left(\mathrm{Ni}^{2+}\right){ }^{26,45}$ With the increase in $\mathrm{Ni}$ content, this peak becomes slightly sharper.

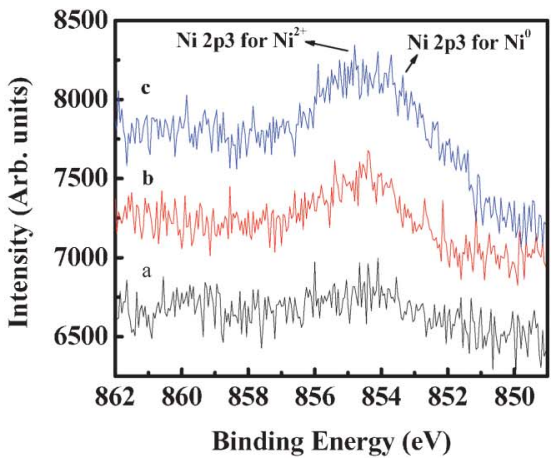

Fig. 5 XPS results of Ni/C composite nanofibers with different Ni contents: (a) 5, (b) 12, and (c) $16 \mathrm{wt} \%$. 

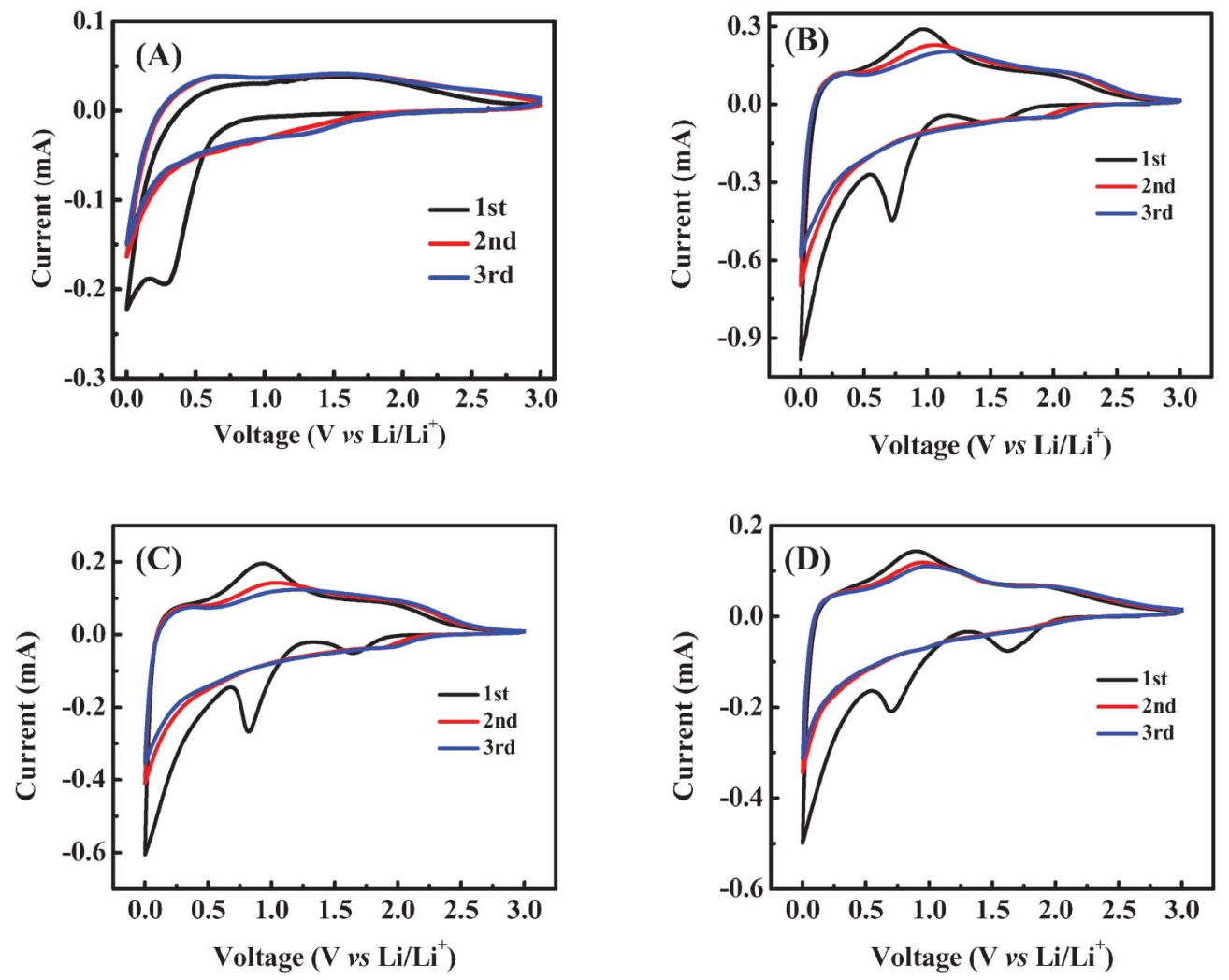

Fig. $6 \mathrm{CV}$ curves of Ni/C composite nanofibers with different Ni contents: (A) 0 (pure CNFs), (B) 5, (C) 12, and (D) $16 \mathrm{wt} \%$.

\section{Electrochemical performance}

Fig. 6 shows the CV curves of pure CNFs and Ni/C composite nanofibers. In the first cycle, pure CNF anodes exhibit a clear cathodic peak at about $0.5 \mathrm{~V}$, corresponding to the formation of a SEI film. ${ }^{46} \mathrm{Ni} / \mathrm{C}$ composite nanofiber anodes exhibit two cathodic peaks at about 0.75 and $1.70 \mathrm{~V}$, respectively. These peaks were related to the formation of partially reversible SEI film and the $\mathrm{Li}$ insertion into $\mathrm{NiO}$ impurities, forming $\mathrm{Li}_{2} \mathrm{O}$ and metallic $\mathrm{Ni}^{47}$ With increase in $\mathrm{Ni}$ content, the peak intensity at $0.75 \mathrm{~V}$ decreases, while the peak intensity at $1.70 \mathrm{~V}$ increases. For $\mathrm{Ni} / \mathrm{C}$ nanofiber anodes, a wide peak at about $1.05 \mathrm{~V}$ and a very small peak at around $2.0 \mathrm{~V}$ are also recorded in the first anodic process. The peak at $1.05 \mathrm{~V}$ can be attributed to the partial decomposition of SEI, while the one at $2.0 \mathrm{~V}$ corresponds to the decomposition of $\mathrm{Li}_{2} \mathrm{O}$ and the conversion of $\mathrm{Ni}$ back to NiO. In the subsequent cycles, the reduction peak at $0.75 \mathrm{~V}$ disappears, and the peak at $1.70 \mathrm{~V}$ becomes smaller and shifts to slightly higher voltage, while all of the oxidation peaks show slightly decreased intensities.

Fig. 7A-C shows typical charge (lithium insertion)/discharge (lithium extraction) curves of $\mathrm{Ni} / \mathrm{C}$ composite nanofibers at a constant current density of $50 \mathrm{~mA} \mathrm{~g}^{-1}$ with a potential window of $0.01-2.8$ V. From Fig. $7 \mathrm{~A}-\mathrm{C}$, it is seen that during the first charge process, the voltages steeply decrease to about $0.9-1.0 \mathrm{~V}$ and then slowly decrease until total charge capacities of 901, 1245 , and $895 \mathrm{mAh}^{-1}$ are reached, respectively, for $\mathrm{Ni} / \mathrm{C}$ composite nanofibers with 5,12 , and $16 \mathrm{wt} \% \mathrm{Ni}$. The plateau at 0.9-1.0 V may be associated with the electrolyte decomposition and the formation of solid electrolyte interface (SEI) films, and it may be caused by the initial reduction of amorphous $\mathrm{NiO}$ impurities to $\mathrm{Ni}$ and $\mathrm{Li}_{2} \mathrm{O} .{ }^{47,48}$ The corresponding first-cycle discharge profiles of Ni/C composite nanofibers show a slight polarization at around $0.75 \mathrm{~V}$, followed by smoothly increasing curves. For $\mathrm{Ni} / \mathrm{C}$ composite nanofibers with 5 , 12, and $16 \mathrm{wt}^{\%} \%$ $\mathrm{Ni}$, the first-cycle discharge capacities are about 558, 728, and $475 \mathrm{mAh} \mathrm{g}^{-1}$, corresponding to Coulombic efficiencies of 62, 59, and $53 \%$, respectively. These relatively small Coulombic efficiencies can be attributed to the decomposition of the electrolyte and the formation of SEI film and other inactive materials. ${ }^{12,49,50}$ However, after the first cycle, the Coulombic efficiencies of $\mathrm{Ni} / \mathrm{C}$ composites remain nearly $100 \%$. Moreover, the discharge capacities of $\mathrm{Ni} / \mathrm{C}$ composite nanofiber anodes are about 488, 662, and $433 \mathrm{mAh} \mathrm{g}^{-1}$, respectively, at the second cycle. Compared to the charge/discharge capacities of pure CNFs reported in our previous work and others, ${ }^{3,11,23,29,31,51}$ $\mathrm{Ni} / \mathrm{C}$ composite nanofibers with $12 \mathrm{w} \% \mathrm{Ni}$ have improved initial reversible capacity $\left(662 \mathrm{mAh}^{-1}\right)$. The reversible capacity of CNFs is about $490 \mathrm{mAh} \mathrm{g}^{-1}$ at $50 \mathrm{~mA} \mathrm{~g}^{-13,11,29,51}$ The relatively high capacities of $12 \mathrm{wt} \% \mathrm{Ni} / \mathrm{C}$ composite nanofibers might be due to the synergetic effects of the carbon matrix and $\mathrm{Ni}$ nanoparticles as well as the special nanostructures of the asprepared $\mathrm{Ni} / \mathrm{C}$ composites.

The cycling performance of $\mathrm{Ni} / \mathrm{C}$ composite nanofibers is shown in Fig. 7D. After fifty cycles, the reversible capacities remain relatively constant, i.e., 377, 549, $397 \mathrm{mAh} \mathrm{g}^{-1}$, respectively, for $\mathrm{Ni} / \mathrm{C}$ composite nanofibers with 5, 12, and $16 \mathrm{wt} \% \mathrm{Ni}$. These capacity values correspond to $68,75,82 \%$ capacity retention from the first-cycle values, which indicate a relatively slow capacity fading. The reversible capacities of all three $\mathrm{Ni} / \mathrm{C}$ 

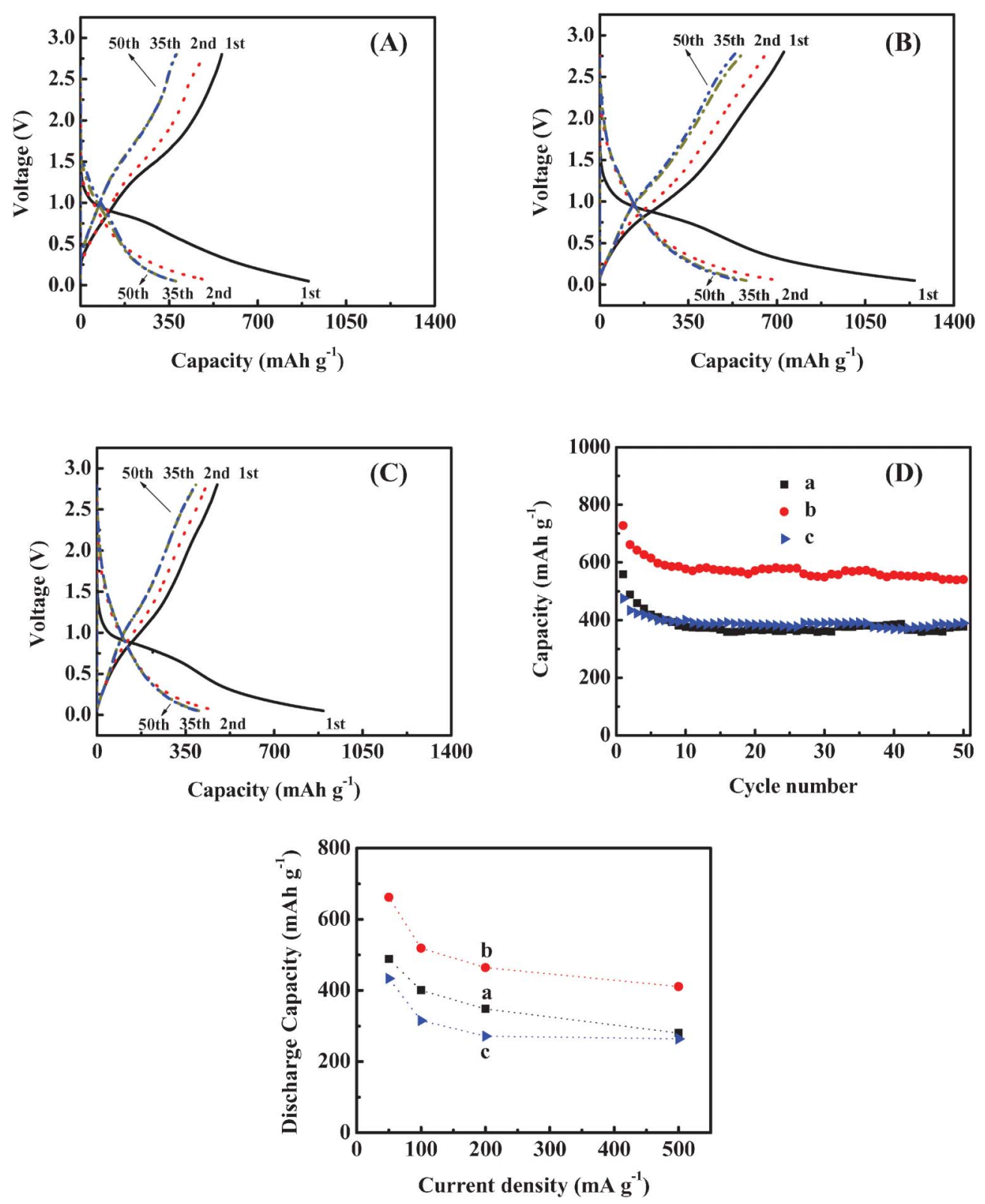

Fig. 7 Charge-discharge curves of $\mathrm{Ni} / \mathrm{C}$ composite nanofibers with different Ni contents: (A) 5, (B) 12 , and (C) $16 \mathrm{wt} \%$. Current density: $50 \mathrm{~mA} \mathrm{~g}^{-1}$. (D) Cycling performance of $\mathrm{Ni} / \mathrm{C}$ composite nanofibers with different Ni contents: (a) 5, (b) 12 , and (c) $16 \mathrm{wt} \%$. Current density: $50 \mathrm{~mA} \mathrm{~g}{ }^{-1}$. (E) Rate capabilities of $\mathrm{Ni} / \mathrm{C}$ composite nanofibers with different $\mathrm{Ni}$ contents: (a) 5, (b) 12, and (c) $16 \mathrm{wt} \%$.

composite nanofibers after 50 cycles are still higher than the theoretical capacity $\left(372 \mathrm{mAh} \mathrm{g}^{-1}\right)$ of graphite and other reported $\mathrm{Ni} / \mathrm{NiO}^{27}$ or $\mathrm{C} / \mathrm{NiO}$ nanocomposites. ${ }^{52}$ The relatively good cycling performance of $\mathrm{Ni} / \mathrm{C}$ composite nanofibers can be ascribed to their unique composite structure, such as the increase in electrode connectivity due to the addition of inactive Ni nanoparticles, the unique one-dimensional fiber structure, and the effective lithium ion transportation at the large nanofiber surfaces. ${ }^{3,26}$

The second-cycle discharge capacities of $\mathrm{Ni} / \mathrm{C}$ composite nanofibers at different current densities of 50,100, 200, and $500 \mathrm{~mA} \mathrm{~g}^{-1}$ are shown in Fig. 7E (rate capability). At a current density of $100 \mathrm{~mA} \mathrm{~g}^{-1}$, capacities of $\mathrm{Ni} / \mathrm{C}$ composite nanofibers show relatively large degradations compared to those at $50 \mathrm{~mA} \mathrm{~g}^{-1}$. However, relatively small capacity decreases are observed when the current density increases from 100 to $200 \mathrm{~mA} \mathrm{~g}^{-1}$. At a much higher current density of $500 \mathrm{~mA} \mathrm{~g}^{-1}$, $\mathrm{Ni} / \mathrm{C}$ composite nanofibers with 5,12 , and $16 \mathrm{wt} \% \mathrm{Ni}$ exhibit reversible capacities of approximately 280, 411, and $263 \mathrm{mAh} \mathrm{g}^{-1}$, respectively, indicating satisfactory rate capability, which has been a problem for the performance of many graphite anodes. ${ }^{23}$ In addition, Ni/C composite nanofibers with $12 \mathrm{wt} \%$ $\mathrm{Ni}$ have a better rate performance than pure CNFs, but $\mathrm{Ni} / \mathrm{CNFs}$ with 5 and $16 \mathrm{wt} \% \mathrm{Ni}$ have similar or even worse performance than pure CNFs. ${ }^{3,11,29,51}$ This indicates that the content of $\mathrm{Ni}$ is very important in determining the performance of $\mathrm{Ni} / \mathrm{C}$ nanofiber anodes. Further explorations are still necessary to identify the potential connections between $\mathrm{Ni}$ content and electrochemical performance. 
The Ni/C composite nanofibers with certain amounts of electrochemically-inert $\mathrm{Ni}$ nanoparticles show high reversible capacity, improved cyclability, and good rate capability because of the unique nanofiber structure and good structural integrity. To obtain good electrochemical performance, electrode materials should always possess the properties of high lithium storage, fast $\mathrm{Li}$ insertion/release kinetics, good electronic and ionic conductivities, and appropriate mechanical strength to stabilize the Liion transfer pathway for Li uptake/removal. A certain amount of electro-inactive $\mathrm{Ni}$ phase in $\mathrm{Ni} / \mathrm{C}$ composite nanofibers may increase the charge transfer in electrode materials along with facilitated Li-ion diffusion, promote the electron transfer, and help avoid the breakdown of the conductive network between current collector and the electrode. The electrochemically-inert metallic $\mathrm{Ni}$ phase can also act as a catalyst to facilitate $\mathrm{Li}_{2} \mathrm{O}$ decomposition, and suppress or stabilize the formation of SEI layers, which in turn improves the Coulombic efficiency. $3,24-26,28,47,53$ At the same time, the existence of homogeneous-dispersed $\mathrm{Ni}$ particles can create a large amount of defects and help activate the carbon nanofibers, which in turn can enhance the Li-storage and improve the electrochemical performance of $\mathrm{Ni} / \mathrm{C}$ composite nanofibers.

\section{Conclusions}

$\mathrm{Ni} / \mathrm{C}$ composite nanofibers were fabricated through electrospinning and thermal treatment processes of $\mathrm{Ni}(\mathrm{OAc})_{2} \cdot 4 \mathrm{H}_{2} \mathrm{O} / \mathrm{PAN}$ precursors with different concentrations. These Ni/C composite nanofibers exhibited high reversible capacity, improved cyclic retention, and acceptable rate capability when used as binderfree anode materials for LIBs. When the Ni content was $12 \mathrm{wt} \%$, $\mathrm{Ni} / \mathrm{C}$ composite nanofibers delivered the highest reversible capacities of 728 and $541 \mathrm{mAh} \mathrm{g}^{-1}$ at the first and 50th cycles, corresponding to a capacity retention of $75 \%$, at the current density of $50 \mathrm{~mA} \mathrm{~g}^{-1}$. When the current density increased to $500 \mathrm{~mA} \mathrm{~g}^{-1}, \mathrm{Ni} / \mathrm{C}$ composite nanofibers showed relatively small capacity degradation compared with those at $50 \mathrm{~mA} \mathrm{~g}^{-1}$. The good electrochemical performance of $\mathrm{Ni} / \mathrm{C}$ composite nanofibers is a result of the cooperative effects of $\mathrm{Ni}$ nanoparticles and the carbon matrix, as well as the unique one-dimensional nanofiber structure with large surface area and high length/diameter ratio.

\section{Acknowledgements}

This work was supported by the U.S. Department of Energy (NO. DE-EE0001177) and the ERC Program of the National Science Foundation under Award Number EEC-08212121.

\section{References}

1 Y.-G. Guo, J.-S. Hu and L.-J. Wan, Adv. Mater., 2008, 20, 2878.

2 L. Ji, Z. Lin, M. Alcoutlabi and X. Zhang, Energy Environ. Sci, 2011, 4, 2682.

3 L. Ji, Z. Lin, A. J. Medford and X. Zhang, Chem.-Eur. J., 2009, 15, 10718.

4 C. Liu, F. Li, L.-P. Ma and H.-M. Cheng, Adv. Mater., 2010, 22, E28.

5 H. Li, Z. Wang, L. Chen and X. Huang, Adv. Mater., 2009, 21, 4593.

6 D. Liu and G. Cao, Energy Environ. Sci., 2010, 3, 1218.

7 Y. S. Meng and M. E. Arroyo-de Dompablo, Energy Environ. Sci, 2009, 2, 589.

8 R. Liu, J. Duay and S. B. Lee, Chem. Commun., 2011, 47, 1384.

9 K. Xu, Energies, 2010, 3, 135.
10 B. Kang and G. Ceder, Nature, 2009, 458, 190.

11 L. Ji, Z. Lin, B. Guo, A. J. Medford and X. Zhang, Chem.-Eur. J., 2010, 16, 11543 .

12 L. Ji, Z. Tan, T. R. Kuykendall, S. Aloni, S. Xun, E. Lin, V. Battaglia and Y. Zhang, Phys. Chem. Chem. Phys., 2011, 13, 7170.

13 F.-C. Liu, W.-M. Liu, M.-H. Zhan, Z.-W. Fu and H. Li, Energy Environ. Sci., 2011, 4, 1261.

14 N. A. Kaskhedikar and J. Maier, Adv. Mater., 2009, 21, 2664.

15 S. W. Lee, B. M. Gallant, H. R. Byon, P. T. Hammond and Y. ShaoHorn, Energy Environ. Sci., 2011, 4, 1972.

16 H. Gwon, H.-S. Kim, K. U. Lee, D.-H. Seo, Y. C. Park, Y.-S. Lee, B. T. Ahn and K. Kang, Energy Environ. Sci., 2011, 4, 1277.

17 L. Hu, D. S. Hecht and G. Grüner, Chem. Rev., 2010, 110, 5790.

18 M. Pumera, Energy Environ. Sci., 2011, 4, 668.

19 Y. Sun, Q. Wu and G. Shi, Energy Environ. Sci., 2011, 4, 1113.

20 G. Lota, K. Fic and E. Frackowiak, Energy Environ. Sci., 2011, 4, 1592.

21 S. Chen, H. Hou, F. Harnisch, S. A. Patil, A. A. Carmona-Martinez, S. Agarwal, Y. Zhang, S. Sinha-Ray, A. L. Yarin, A. Greiner and U. Schroder, Energy Environ. Sci., 2011, 4, 1417.

22 W.-J. Zhang, J. Power Sources, 2011, 196, 13.

23 C. Kim, K. S. Yang, M. Kojima, K. Yoshida, Y. J. Kim, Y. A. Kim and M. Endo, Adv. Funct. Mater., 2006, 16, 2393.

24 M.-S. Park, S. Rajendran, Y.-M. Kang, K.-S. Han, Y.-S. Han and J.-Y. Lee, J. Power Sources, 2006, 158, 650.

25 Y.-M. Kang, K.-T. Kim, J.-H. Kim, H.-S. Kim, P. S. Lee, J.-Y. Lee, H. K. Liu and S. X. Dou, J. Power Sources, 2004, 133, 252.

26 H.-R. Jung and W.-J. Lee, J. Electrochem. Soc., 2011, 158, A644.

27 X. H. Huang, J. P. Tu, B. Zhang, C. Q. Zhang, Y. Li, Y. F. Yuan and H. M. Wu, J. Power Sources, 2006, 161, 541.

28 J. Hassoun, S. Panero, P. Simon, P. L. Taberna and B. Scrosati, $A d v$. Mater., 2007, 19, 1632.

29 L. Ji, A. J. Medford and X. Zhang, J. Mater. Chem., 2009, 19, 5593.

30 L. Ji, A. J. Medford and X. Zhang, Polymer, 2009, 50, 605.

31 L. Ji, K.-H. Jung, A. J. Medford and X. Zhang, J. Mater. Chem., 2009, 19, 4992.

32 O. Toprakci, L. Ji, Z. Lin, H. A. K. Toprakci and X. Zhang, J. Power Sources, 2011, 196, 7692.

33 J. Kim, Y. C. Kim, W. Ahn and C. Y. Kim, Polym. Eng. Sci., 1993, 33, 1452.

34 L. Ji, Z. Lin, Y. Li, S. Li, Y. Liang, O. Toprakci, Q. Shi and X. Zhang, Polymer, 2010, 51, 4368.

35 M. A. Mohamed, S. A. Halawy and M. M. Ebrahim, J. Anal. Appl. Pyrolysis, 1993, 27, 109.

36 J. Hong, G. Guo and K. Zhang, J. Anal. Appl. Pyrolysis, 2006, 77, 111.

37 J. C. De Jesus, I. González, A. Quevedo and T. Puerta, J. Mol. Catal. A: Chem., 2005, 228, 283.

38 G. Hussein, A. Nohman and K. Attyia, J. Therm. Anal., 1994, 42, 1155.

39 H. Wu, R. Zhang, X. Liu, D. Lin and W. Pan, Chem. Mater., 2007, 19, 3506 .

40 N. A. M. Barakat, B. Kim and H. Y. Kim, J. Phys. Chem. C, 2008, 113,531

41 I. M. Afanasov, O. N. Shornikova, V. V. Avdeev, O. I. Lebedev, G. V. Tendeloo and A. T. Matveev, Carbon, 2009, 47, 513.

42 Z. Bai, H. Chen, B. Li and W. Li, Int. J. Hydrogen Energy, 2007, 32, 32.

43 L. M. Gandia and M. Montes, J. Catal., 1994, 145, 276.

44 M. S. A. Rahaman, A. F. Ismail and A. Mustafa, Polym. Degrad. Stab., 2007, 92, 1421.

45 A. P. Grosvenor, M. C. Biesinger, R. S. C. Smart and N. S. McIntyre, Surf. Sci., 2006, 600, 1771.

46 X. X. Wang, J. N. Wang, H. Chang and Y. F. Zhang, Adv. Funct. Mater., 2007, 17, 3613.

47 Y. J. Mai, J. P. Tu, X. H. Xia, C. D. Gu and X. L. Wang, J. Power Sources, 2011, 196, 6388.

48 H. Liu, G. Wang, J. Liu, S. Qiao and H. Ahn, J. Mater. Chem., 2011, 21, 3046.

49 X. Liu, Y.-S. Hu, J.-O. Müller, R. Schlögl, J. Maier and D. S. Su, ChemSusChem, 2010, 3, 261.

50 Y.-S. Hu, X. Liu, J.-O. Müller, R. Schlögl, J. Maier and D. S. Su, Angew. Chem., Int. Ed., 2009, 48, 210.

51 L. Ji, Z. Lin, A. J. Medford and X. Zhang, Carbon, 2009, 47, 3346.

52 M. M. Rahman, S.-L. Chou, C. Zhong, J.-Z. Wang, D. Wexler and H.-K. Liu, Solid State Ionics, 2010, 180, 1646.

53 M. D. Fleischauer, M. N. Obrovac, J. D. McGraw, R. A. Dunlap, J. M. Topple and J. R. Dahn, J. Electrochem. Soc., 2006, 153, A484. 